DOI: $10.21802 / \mathrm{artm} .2019 .4 .12 .119$.

УДК 616.379-008.64+616-092.9+546.15

\title{
ВПЛИВ ІНСУЛІНОРЕЗИСТЕНТНОСТІ НА ТИРЕОЇДНИЙ ГОМЕОСТАЗ ЩУРІВ ЗА УМОВ ВРОДЖЕНОГО ТА НАБУТОГО ЙОДОДЕФІЦИТУ
}

\author{
В.Б. Стецев'ят, Н.М. Воронич-Семченко
}

Івано-Франківський начіональний медичний університет, кафедра фізіології, м. Івано-Франківськ, Україна,

ORCID ID: 0000-0001-6465-5282,

ORCID ID: 0000-0001-9872-6640,

e-mail:f10bff@gmail.com

Резюме. Зважаючи на поширеність цукрового діабету, високий ризик розвитку йододефіцитних захворювань в Україні, особливо в ендемічних регіонах, представляє інтерес з'ясування тиреоїдного профілю за умов інсулінорезистентності. Такі дані дозволять розширити профілактичні заходи та діагностику мінімальної тиреоїдної недостатності. Мета дослідження - дослідити вплив інсулінорезистентності на тиреоїдний гомеостаз щурів за умов вродженого та набутого йододефіциту з урахування статевого диморфізму.

У результаті дослідження у сироватці крові інсулінорезистентних тварин виявили зменшення вмісту тиреотропного гормону аденогіпофіза - ТТГ (достовірними були тільки зміни у самок - на $43 \%, \mathrm{p}_{1-2}<0,05$ ), вільного трийодтироніну ( $\left.\mathrm{fT}_{3}\right)$ - у самців та самок на 36 та $39 \%\left(\mathrm{p}_{1-2}<0,05\right)$ відповідно, тоді як рівень вільного тироксину (f( $\left.\mathrm{f}_{4}\right)$ достовірно не відрізнявся від контролю. Така динаміка зумовила суттєве зниження індекса ТTГ/fT 4 (більше у самок) щодо вихідних даних. Підтверджено, що інсулінорезистентність порушує механізми гіпоталамо-гіпофізарної регуляції, що супроводжується змінами компенсаторної реакції щитоподібної залози на вплив струмогенів. Тому маркерами для діагностики порушень тиреоїдного гомеостазу за умов інсулінорезистентності є зниження індексів ТТГ/fT 4 , $\mathrm{fT}_{3} / \mathrm{fT}_{4}$. Йододефіцит супроводжується переважною секрецією $\mathrm{fT}_{3}$ на тлі гіпертиреотропії, що зумовлює зростання ТТГ/fT 4 , а також індекса периферичної конверсії $\mathrm{fT}_{3} / \mathrm{fT}_{4}$. Таким чином, встановлено, що інсулінорезистентність $€$ фактором ризику розвитку гіпотиреоїдної дисфункції. Більш небезпечним є розвиток інсулінорезистентності на тлі йододефіциту (особливо за умов вродженої йодної депривації). Ймовірність формування тиреоїдної дисфункції вища у статевозрілих самок.

Ключові слова: інсулінорезистентність, йододефіцит, статевий диморфізм, тиреоїдний статус, гіпоталамо-гіпофізарна система.

Вступ. Актуальність дослідження зумовлена неухильною тенденцією до зростання поширеності цукрового діабету 2 типу і предіабету, особливо у жінок. При цьому близько 11 \% хворих на цукровий діабет мають порушення тиреоїдного гомеостазу [2, 4, 5]. В останні роки більше уваги приділяється підвищенню ефективності профілактики інсулінорезистентності, запобіганню розвитку клінічної маніфестації захворювання та ускладнень з боку окремих органів та систем, що дозволить підвищити якість життя та продовжити його тривалість.

Обгрунтованість дослідження. Некорегована гіперглікемія за умов інсулінорезистентності здатна запускати низку метаболічних порушень. Відомо, що у хворих на цукровий діабет спостерігається зниження вмісту тиреотропного гормону аденогіпофізу (ТТГ) у сироваці крові (зменшується нічна пікова секреція ТТГ, а також порушується відповідь на стимуляцію тиреоліберином гіпоталамуса) [1]. Зважаючи на високий ризик розвитку йододефіцитних захворювань в Україні, особливо в ендемічних регіонах, представляє інтерес з'ясування тиреоїдного профілю за умов інсулінорезистентності. Відомо, що порушення функціонування гіпоталамо-гіпофізарнотиреоїдної осі супроводжується зміною регуляції чутливості до глюкози. Це дозволяє стверджувати про вагому роль гіпоталамуса у підтриманні вуглеводного обміну. Тому представляє науковий інтерес вивчення динаміки змін тиреоїдного гомеостазу за умов порушеного вуглеводного балансу та йодного дефіциту, особливо вродженого. Такі дані дозволять розширити профілактичні заходи збереження функціональної здатності щитоподібної залози мешканцям ендемічних регіонів та діагностику мінімальної тиреоїдної недостатності.

Мета дослідження: дослідити вплив інсулінорезистентності на тиреоїдний гомеостаз щурів за умов вродженого та набутого йододефіциту 3 урахування статевого диморфізму.

Матеріали та методи. Дослідження проводили на нелінійних статевозрілих щурах (самцях та самках) масою 150-180 г, які були розділені на шість дослідних груп: 1-ша - контрольна (інтактні тварини, 15 самців та 15 самок), 2-га - інсулінорезистентні тварини (15 самців та 15 самок), 3-тя - тварини із вродженим дефіцитом йоду (15 самців та 15 самок), 4-та - тварини із набутим йододефіцитом (15 самців та 15 самок), 5-та - інсулінорезистентні тварини, які перебували на йододефіцитній дієті у другому поколінні (15 самців та 15 самок), 6-та - інсулінорезистентні тварини, які перебували на йододефіцитній дієті після статевого дозрівання (15 самців та 15 
самок). Інсулінорезистентність тваринам моделювали шляхом додавання до питної води $10 \%$ розчину фруктози впродовж 8-ми тижнів (2-га, 5-та та 6-та дослідні групи) [5]. Тварини 3-6-ї дослідних груп отримували йододефіцитну дієту, зокрема, 3-ї та 5-ї перебували на дієті у другому поколінні, 4-ї та 6-ї впродовж 45 днів експерименту [3]. Щури контрольної групи знаходились на стандартному харчовому раціоні. Утримання, вигодовування та евтаназія (декапітація під кетаміновим знечуленням, 100 мг/кг маси тіла) відповідали чинним міжнародним вимогам щодо гуманного відношення до тварин.

Для оцінки тиреоїдного статусу тварин визначали вміст вільних трийодтироніну (fT 3 ) та тироксину (fT 4 ), ТТГ у сироватці крові методом імуноферментного аналізу з наступним визначенням індексів $\mathrm{fT}_{3} / \mathrm{fT}_{4}$ та TTГ/fT 4 . Стан йодного забезпечення щурів оцінювали за концентрацією йоду у добових порціях сечі, яку збирали методом обмінних кліток. Вуглеводневий обмін характеризували за рівнем глікозильованого гемоглобіну у цільній крові, вмістом глюкози та імунореактивного інсуліну у сироватці крові натще та обчислювали індекси HOMA-IR (Homeostasis Model Assesment Insulin Resistane) i Caro. Параметричний аналіз отриманих peзультатів проводили 3 використанням t-критерію Стьюдента.

Результати та їх обговорення. У результаті дослідження на розвиток інсулінорезистентності у тварин 2-ї, 5-ї та 6-ї груп вказують зростання глікозильованого гемоглобіну у цільній крові (більше, ніж у два рази, $\mathrm{p}<0,05)$, вмісту глюкози (у два - три рази, $\mathrm{p}<0,05$ ) та імунореактивного інсуліну (на 28-34 \%, $\mathrm{p}<0,05)$, індексів HOMA-IR (у три-чотири рази, $\mathrm{p}<0,05)$ i Caro (майже у два рази, $\mathrm{p}<0,05)$ щодо контрольних значень.

У тварин усіх дослідних груп спостерігали зміни тиреоїдного статусу (див. рис. 1). Так, у сироватці крові тварин 2-ї дослідної групи (інсулінорезистентні щури) виявили зменшення вмісту ТТГ (достовірними були тільки зміни у самок - на $43 \%$, $\mathrm{p}_{1-}$ $\left.{ }_{2}<0,05\right), \mathrm{fT}_{3}-$ у самців та самок на 36 та $39 \%\left(\mathrm{p}_{1-}\right.$ $\left.{ }_{2}<0,05\right)$ відповідно, тоді як рівень $\mathrm{fT}_{4}$ достовірно не відрізнявся від контролю. Така динаміка зумовила суттєве зниження індекса ТТГ/fT 4 (більше у самок) щодо вихідних даних. За таких умов вміст йоду в сечі достовірно не відрізнявся від значень у інтактних тварин. Зазначені зміни тиреоїдного статусу можуть бути наслідком захисного механізму організму у відповідь на підвищені процеси катаболізму та зниження споживання кисню тканинами. Відомо, що при порушенні глікемічного контролю пригнічується активність $\mathrm{T}_{4}-5$-дейодинази III типу (ензим виявляє свою активність у мозку), що супроводжується сповільненням конверсії $\mathrm{T}_{4}$ у $\mathrm{T}_{3}$, зниженням рівня $\mathrm{T}_{3}$ у сироватці та зростанням концентрації реверсивного $\mathrm{T}_{3}\left(\mathrm{rT}_{3}\right)[2,3]$.

У щурів 3-ї дослідної групи (тварини із вродженим йододефіцитом) виявили зменшення вмісту $\mathrm{fT}_{3}$ у сироватці крові (на 50-66 \% незалежно від статі, $\mathrm{p}<0,05)$ щодо контролю. Такі зміни розвивались на тлі суттєвого зростання вмісту ТТГ у сироватці крові
- у 2,3 раза $\left(\mathrm{p}_{1-3}<0,01\right)$ у самців та у 1,6 раза $\left(\mathrm{p}_{1-}\right.$ $\left.{ }_{3}<0,05\right)$ у самок щодо даних у інтактних тварин. У цій групі тварин гендерні особливості виявлених змін не були достовірними. Можна припустити, що вроджений йододефіцит вплинув на статевий гормональний профіль щурів. Вміст йоду в сечі тварин цієї дослідної групи не перевищував $(15,0+0,06)$ мкг/л.

У щурів 4-ї дослідної групи (тварини із набутим йододефіцитом) зміни тиреоїдного статусу не були такими вираженими, що можна пояснити тривалістю перебування тварин на йододефіцитній дієті. Проте було зафіксовано тенденцію зростання рівня ТТГ у сироватці крові дослідних тварин щодо контролю. У самців цієї дослідної групи рівень ТТГ у сироватці крові перевищив дані тварин з інсулінорезистентністю, проте рівень гормону був меншим, ніж у тварин із вродженим йододефіцитом. Вміст $\mathrm{fT}_{3}$ та $\mathrm{fT}_{4}$ у сироватці крові тварин 4-ї дослідної групи був менший на 28 і $34 \%\left(\mathrm{p}_{1-4}<0,05\right)$ та на 37 i $35 \%\left(\mathrm{p}_{1-}\right.$ $\left.{ }_{4}<0,05\right)$ у самців та самок відповідно щодо вихідних даних. Можна стверджувати, що за умов набутого йододефіциту щитоподібна залоза секретує більше $\mathrm{fT}_{3}$ [3]. У результаті проведення порівняльного аналізу показників у тварин 3-ї та 4-ї дослідних груп підтверджено, що вроджений йододефіцит супроводжується більш глибокими порушеннями тиреоїдного гомеостазу. Вміст йоду у сечі щурів цієї дослідної групи був на $65-73 \%\left(\mathrm{p}_{1-4}<0,05, \mathrm{p}_{2-4}<0,05\right)$ меншим, ніж у інтактних тварин, але на 28-31\% $\left(\mathrm{p}_{3-4}<0,05\right)$ більшим, ніж у тварин із вродженою йодною депривацією.

У тварин із комбінованою ендокринною патологією (5-та та 6-та дослідні групи) виявили потенціювання змін показників гіпоталамо-гіпофізарнотиреоїдної осі. Зокрема, у сироватці крові тварин 5-ї дослідної групи вміст $\mathrm{fT}_{3}$ та $\mathrm{fT}_{4}$ був менший на 73 і 82 $\%\left(\mathrm{p}_{1-5}<0,05\right)$ та на 65 і $66 \%\left(\mathrm{p}_{1-5}<0,05\right)$ у самців та самок відповідно щодо вихідних даних. Функціональна здатність щитоподібної залози тварин 6-ї дослідної групи мала співнапрямлені, але менш виражені зміни. Привертає увагу порушення секреції ТТГ аденогіпофізом інсулінорезистентних тварин, незважаючи на їх перебування на йододефіцитній дієті.

Загалом інсулінорезистентність змінює центральні механізми гіпоталамо-гіпофізарної регуляції, що супроводжується розладами компенсаторної реакції щитоподібної залози на вплив струмогенів. За таких умов поліорганні зміни у результаті гіпотиреоїдної недостатності розвиваються інтенсивніше. Відомо, що раннім маркером мінімальної тиреоїдної недостатності та субклінічного гіпотиреозу є показник ТТГ у сироватці крові. Йододефіцит супроводжується переважною секрецією $\mathrm{fT}_{3}$ на тлі гіпертиреотропії, що зумовить зміни ТТГ/fT 4 , а також індекса периферичної конверсії. Зважаючи на динаміку гормонів гіпоталамо-гіпофізарно-тиреоїдної осі за умов інсулінорезистентності (переважна секреція $\mathrm{fT}_{4}$ та зниження ТТГ) інформативним показником зміни тиреоїдного профілю можна вважати обчислення індексу периферичної конверсії ( $\left.\mathrm{fT}_{3} / \mathrm{fT}_{4}\right)$. 


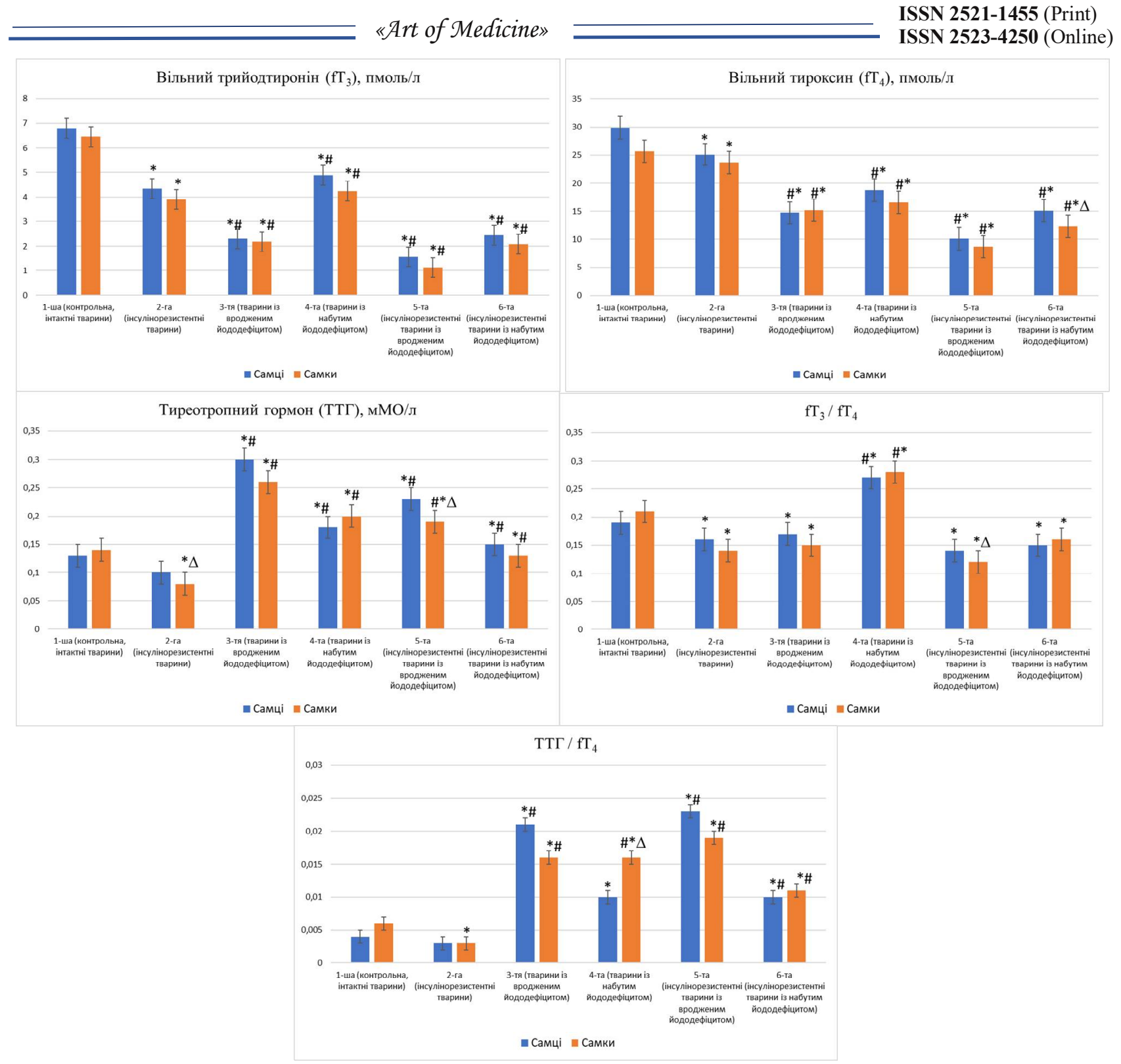

Рис. 1. Показники тиреоїдного статусу у інтактних та інсулінорезистентних тварин за умов вродженого і набутого йододефіциту та за умови їх посднання

$(\mathrm{p}<0,05)$;

Примітка. * - достовірна різниця щодо даних у інтактних тварин з урахуванням статевого диморфізму

\# - достовірна різниця щодо даних у інсулінорезистентних тварин з урахуванням статевого диморфізму $(\mathrm{p}<0,05) ; \Delta$ - достовірна різниця щодо даних у самців у межах дослідної групи.

Висновки. У інсулінорезистентних тварин порушується тиреоїдний гомеостаз та гіпоталамічні механізми його регуляції (зменшується секреція $\mathrm{fT}_{3}$ та ТТГ). Більш небезпечним є розвиток інсулінорезистентності на тлі йододефіциту (особливо за умов вродженої йодної депривації). Для діагностики доклінічних стадій розвитку патології інформативними $є$ обчислення індексів $\mathrm{fT}_{3} / \mathrm{fT}_{4}$ та ТТГ/fT 4 , які дозволяють визначити характер тиреоїдного дисбалансу та припустити генез виявлених змін. Отримані дані можуть лягти в основу клінічних спостережень та сприяти розширенню профілактичних заходів тиреоїдної патології. Ймовірність формування тиреоїдної дисфункції вища у статевозрілих самок.

\section{References:}

1. Ismailov SI, Huliamova KhR, Akhmedova ShU, Maksutova NN. Correlation of diabetes mellitus and thyroid patholigy (literature review). International Journal of Endocrinology. 2015; 3(67):148-152.

2. Kondro MM, Halenova TI, Kuznetsova MYu, Savchuk OM. Ekspresiya insulinovoho retseptora $u$ subklitynnykh fraktsiyakh myazovoyi ta zhyrovoyi tkanyn yak faktor rozvytku tkonynnoyi insulinorezystentnosti u shchuriv za umov vysokokaloriynoyi diyety. Fiziolohichnyy zhurnal. 2013; 59(2):59-63.

3. Nykolyshyn LV, Bahrii MM, Popadynets $\mathrm{OH}$, Voronych-Semchenko NM. Strukturno-funktsionalni 
osoblyvosti hipotalamo-hipofizarno-tyreoidnoi systemy u tvaryn iz defitsytom yodu ta selenu. Naukovyi visnyk Uzhhorodskoho universytetu.- 2014; 1(49):14-18.

4. Khokhla MR, Kleveta HYa, Chayika YaP, Skybitska MI, Sybirna NO. Tsytolohichna ta biokhimichna kharakterystyka peryferychnoyi krovi shchuriv za umov eksperymental'noho tsukrovoho diabetu 1-ho typu ta diyi halehy likarskoyi. Biolohichni studiyi. 2012; 6(1):37-46.

5. Shuprovych AA. Violation of uric acid metabolism in rats with experimental insulin resistant syndrome induced by fructose. Fiziol Zh 2011; 57(1):72-81.

\section{УДК 616.379-008.64+616-092.9+546.15}

\section{ВЛИЯНИЕ ИНСУЛИНОРЕЗИСТЕНТНОСТИ НА ТИРЕОИДНЫЙ ГОМЕОСТАЗ КРЫС В УСЛО- ВИЯХ ВРОЖДЕННОГО И ПРИОБРЕТЕННОГО ЙОДОДЕФИЦИТА}

\section{В.Б. Стецевят, Н.Н. Воронич-Семченко}

\author{
Ивано-Франковский национальный медицинский \\ университет, \\ кафедра физиологии, г. Ивано-Франковск, Украина, \\ ORCID ID: 0000-0001-6465-5282, \\ ORCID ID: 0000-0001-9872-6640, \\ e-mail:f10bff@gmail.com
}

Резюме. Учитывая распространенность сахарного диабета, высокий риск развития йододефицитных заболеваний в Украине, особенно в эндемических регионах, представляет интерес выяснение тиреоидного профиля в условиях инсулинорезистентности. Такие данные позволят расширить профилактические мероприятия и диагностику минимальной тиреоидной недостаточности. Цель исследования - исследовать влияние инсулинорезистентности на тиреоидный гомеостаз крыс в условиях врождённого и приобретенного йододефицита, учитывая половой диморфизм.

В результате исследования в сыроватке крови инсулинорезистентных животных обнаружили уменьшение содержания тиреотропного гормона аденогипофиза - ТТГ (достоверными были только изменения у самок - на $\left.43 \%, \mathrm{p}_{1-2}<0,05\right)$, свободного трийодтиронина ( $\left.\mathrm{fT}_{3}\right)$ - у самцов и самок на 36 та $39 \%\left(\mathrm{p}_{1-2}<0,05\right)$ соответственно, тогда как уровень свободного тироксина (fT 4 ) достоверно не отличался от контроля. Такая динамика обусловила существенное снижение индекса ТТГ/fT 4 (больше у самок) относительно исходных данных. Подтверждено, что инсулинорезистентность нарушает механизмы гипоталамо-гипофизарной регуляции, что сопровождается изменениями компенсаторной реакции щитовидной железы на влияние струмогенов. Поэтому маркерами для диагностики нарушений тиреоидного гомеостаза в условиях инсулинорезистентности является снижение индексов ТТГ $/ \mathrm{fT}_{4}, \mathrm{fT}_{3} / \mathrm{fT}_{4}$. Йододефицит сопровождается преимущественно секрецией $\mathrm{fT}_{3}$ на фоне гипертиреотропии, что обусловливает увеличение $\mathrm{TT \Gamma} / \mathrm{fT}_{4}$, а также индекса периферической конверсии $\mathrm{fT}_{3} / \mathrm{fT}_{4}$. Таким образом, установлено, что инсулиноре- зистентность является фактором риска развития гипотиреоидной дисфункции. Более опасным является развитие инсулинорезистентности на фоне йододефицита (особенно в условиях врождённой йодной депривации). Вероятность формирования тиреоидной дисфункции выше у половозрелых самок.

Ключевые слова: инсулинорезистентность, йододефицит, половой диморфизм, тиреоидный статус, гипоталамо-гипофизарная система.

\section{UDC 616.379-008.64+616-092.9+546.15 \\ INFLUENCE OF INSULIN RESISTANCE ON THE THYROID HOMEOSTASIS OF RATS IN CONDITIONS OF CONGENITAL AND ACQUIRED IODINE DEFICIENCY}

\author{
V.B. Stetseviat, N.M. Voronych-Semchenko
}

Ivano-Frankivsk National Medical University, Department of Physiology, Ivano-Frankivsk, Ukraine, ORCID ID: 0000-0001-6465-5282, ORCID ID: 0000-0001-9872-6640, e-mail:f10bff@gmail.com

Abstract. The relevance of the study is driven by a steady tendency to the increase of the prevalence of type 2 diabetes mellitus and prediabetes, especially in women. At the same time, about $11 \%$ of patients with diabetes mellitus have disorders of thyroid homeostasis. Uncorrected hyperglycemia under the conditions of insulin resistance is capable of triggering a number of metabolic disorders. Taking into account the high risk of iodine deficiency in Ukraine, especially in endemic regions, it is of high interest to find out the thyroid profile under thconditions of insulin resistance. Such data will allow us to extend the prevention measures and diagnostics of minimal thyroid insufficiency. The aim of the study is to investigate the influence of insulin resistance on the thyroid homeostasis of rats in the context of congenital and acquired iodine deficiency, taking into account sexual dimorphism.

The studies were performed using non-linear mature rats (males and females) weighing 150-180 g, which were divided into six groups: group I - control (intact animals); group II - insulin-resistant animals; group III - animals with congenital iodine deficiency; group IV - animals with acquired iodine deficiency; group V - insulin-resistant animals, for which iodinedeficient diet was used in the second generation; group VI - insulin-resistant animals for which iodine-deficient diet was used after puberty. Insulin resistance in animals was simulated by adding $10 \%$ fructose solution to drinking water for 8 weeks (experimental groups II, V and VI). Animals in the study groups III-VI have received an iodine-deficient diet, in particular, in the groups III and V - diet in the second generation was used, in the groups IV and VI - diet was used for 45 days of the experiment. Rats from the control group were on a standard diet. Animal care, feeding and euthanasia (decapitation under ketamine anaesthetization, $100 \mathrm{mg} / \mathrm{kg}$ 
of body weight) met current international animal humane treatment requirements.

As a result of the study in the blood serum of insulin-resistant animals, there was found a decrease of the content of thyroid-stimulating hormone in adenogipophysis - TSH (only changes in females - at $43 \%, \mathrm{p}_{1-2}<0.05$ were reliable), free triiodothyronine $\left(\mathrm{fT}_{3}\right)$ - in males and females at 36 and $39 \%\left(\mathrm{p}_{1-2}<0.05\right)$, respectively, whereas the level of free thyroxine $\left(\mathrm{fT}_{4}\right)$ was not significantly different from control. Such dynamics caused a significant decrease of the $\mathrm{TSH} / \mathrm{fT}_{4}$ index (more in females) relative to the initial data. It has been confirmed that insulin resistance violates the central mechanisms of hypothalamic-pituitary regulation, which is accompanied by changes in the compensatory reaction of the thyroid gland to the influence of strumogenic agents. Therefore, markers for the diagnostics of thyroid homeostasis disorders in conditions of insulin resistance are such indices decrease: $\mathrm{TTH} / \mathrm{fT}_{4}, \mathrm{fT}_{3} / \mathrm{fT}_{4}$. Under these conditions, the iodine content of the urine was not significantly different from those of intact animals. Iodine deficiency is accompanied by a predominant secretion of $\mathrm{T}_{3}$ against the background of hyperthyroidism, which causes an increase of $\mathrm{TSH} / \mathrm{fT}_{4}$, as well as the index of peripheral conversion of $\mathrm{fT}_{3} / \mathrm{fT}_{4}$. Thus, it has been established that insulin resistance is a risk factor for the development of hypothyroid dysfunction. More dangerous is the development of insulin resistance against the background of iodine deficiency (especially in the context of congenital iodine deprivation). The probability of thyroid dysfunction formation is higher in adult females.

Keywords: insulin resistance, iodine deficiency, sexual dimorphism, thyroid status, hypothalamic-pituitary system.

Стаття надійшла в редакцію 27.11.2019 р. 